\title{
THE APPLICATION OF CHEMICAL CRITERIA TO BIOLOGICAL CLASSIFICATION IN THE EIGHTEENTH CENTURY ${ }^{1}$
}

by

\section{C. GOODMAN}

THE INVESTIGATION of animal and vegetable substances, traditionally a part of the chemist's general inquiry into the properties of natural objects, was increasingly pursued in the eighteenth century. Some of these materials were important economically in the various arts of dyeing and tanning, agriculture, and the manufacture of soaps and glues, and of course they continued to supply pharmacy with much of its materia medica.

Medical interests were a strong incentive to the concentrated study of these substances. The men who conducted this chemical research, several of whom were physicians, ${ }^{2}$ believed that great advances in medicine would result. In particular it was thought that this would provide the key to the understanding of the animal economy, for in the nutrition of animals the basic vegetable foods were altered in such a way that they could be incorporated within the body. This was interpreted as the conversion of vegetable into animal substances. It seemed that this process of animalization, as it was called, could be investigated through a comparative chemical examination of animal and vegetable substances.

The parts of animals and plants were subjected to the old technique of distillation in closed vessels, they were treated with various reagents, and attention was given to their remarkable alterations in the natural processes of fermentation and putrefaction. As the work progressed, moves were made to establish the position, in fact false, that animal and vegetable substances were chemically distinguishable.

This conclusion, in turn, seemed to be important for biological classification. Ambiguous living forms, especially marine organisms, had puzzled natural historians since antiquity. Morphological and physiological criteria had failed to establish whether they should be classified as plants, animals or intermediates. In the eighteenth century, and after, attempts were made to arrive at the truth through the application of chemical tests, which appeared to offer a valuable means of distinguishing animals and plants.

\section{THE CHEMICAL ANALYSIS OF ANIMAL AND VEGETABLE SUBSTANCES}

In the early eighteenth century the chemical similarity of plants and animals was stressed. This was the view of Homberg, a physician and a member of the Académie des Sciences. He said that analysis by fire showed that there were two distinct types of material in nature: '.. the class of mineral substances and that of vegetable sub-

\footnotetext{
1 I am greatly indebted to Professor J. Schiller who suggested this problem for research, which will continue to deal with the developments in the nineteenth century.

2 They include Homberg, Louis Lémery, Boerhaave, Beccari, Venel, Berthollet and Fourcroy. Chemistry at this time was taught chiefly in the medical schools.
} 


\section{C. Goodman}

stances, in which we also include animal substances; because plants and animals produce the same principles in analysis, so that it does not seem necessary to divide these into two different classes.' ${ }^{3}$

The distillation of animal and vegetable substances gave the same products: aqueous liquids, foetid oils, volatile salts smelling like urine, ${ }^{4}$ and a residue containing fixed salt. He did say that plants, unlike animals, contained an acid, but he later rejected this difference. ${ }^{5}$

This work offered no striking qualitative distinguishing tests. However, a quantitative distinction was suggested at this time and would often be repeated. This was that the volatile ammoniacal products were produced in much greater quantities in animal analyses compared to plants. ${ }^{6}$ But even this was soon challenged by Louis Lémery, ${ }^{7}$ another member of the Académie des Sciences. He argued, from Bourdelin's analyses, that certain plants in distillation gave so much volatile salt, that if one did not already know that the original materials were vegetable, they would be mistaken for animal substances. These plants were the mushrooms, the garden purslane and the fumitory. $\mathrm{He}$ also insisted that acids were equally present in both plants and animals, and that the idea that animals contained little or no acid was the result of faulty analytical techniques which masked the acid. ${ }^{8}$

Boerhaave also emphasized the similar chemical composition of the plant and animal kingdoms. He thought that there was an extraordinary agreement: '... these two kinds of bodies appear to be vastly near akin in all their properties, and in a great many of them to agree intirely. Hence it is no wonder that animals by their concoctive faculties can subsist intirely upon vegetables with the simple addition of water. The bodies of animals seem almost, in many instances, to be nothing but transmuted vegetables."

This was particularly evident in the distillation of mustard-seed, scurvy-grass, radish, horse-radish, cress and cabbage, all plants of the family Cruciferae. ${ }^{10}$ The phenomena were the same as those accompanying the distillation of hartshorn ${ }^{11}$ and other animal matters; all gave white particles of volatile alkaline salt. Indeed the presence of this in mustard-seed seemed even more evident than in urine, which he said was the most alkalescent of all animal liquids.

'W. Homberg, 'Essays de chimie', Mém. Acad. Sci., 1702, p. 34.

- Ammonia is produced by the distillation of these substances as a result of the decomposition of their protein. White crystals of ammonium carbonate were usually observed.

${ }^{5} \mathrm{~W}$. Homberg, 'Observations sur l'acide qui se trouve dans le sang et dans les autres parties des animaux', Mém. Acad. Sci., 1712, pp. 8-15.

- 'Diverses observations chimiques', Hist. Acad. Sci., 1702, p. 42.

'L. Lémery, 'Quatrième mémoire sur les analyses ordinaires des plantes et des animaux', Mém. Acad. Sci., 1721, p. 30.

8 Ibid., p. 34. He argued that the usual method of distillation would not detect animal acids, since these would be neutralized by the ammoniacal distillate. See also 'Sur les analises ordinaires', Hist. Acad. Sci., 1720, pp. 36-42.

- H. Boerhaave, Elements of Chemistry, trans. T. Dallowe, London, 1735, 2 vols., vol. 1, 375-76. He said acids and fixed alkaline salts were found only in plants, not in animals. However his statement gave the impression that these differences were much less important than the analogies. Compare Needham's remark: 'All have ever allow'd Man in his Origin to be a kind of Plant or Vegetable before he is animated'.

T. Needham, 'A summary of some late observations upon the generation, composition and decomposition of animal and vegetable substances', Phil. Trans., $R$. Soc. Lond., 1748, 45, 665.

10 Boerhaave (n. 9), vol. 2, pp. 97-99.

${ }_{11}$ An old source of ammonia. In the seventeenth century ammonia was sometimes referred to as 'spirit of hartshorn'. 


\section{Application of Chemical Criteria to Biological Classification in the 18th Century}

In the eighteenth century the cruciferous plants were frequently referred to in accounts of the chemical properties of animals and plants. They became a standard exception, preventing a sharp distinction between the two kingdoms on the supposition that volatile alkali was an exclusively animal product. Their chemical properties led to their description as 'animal plants'.12 Their analysis was pursued all the more vigorously because of their anti-scorbutic properties, especially the Cochlearia officinalis or scurvy-grass. ${ }^{13}$

Boerhaave also knew that it was impossible to make a complete separation of plants and animals from their spontaneous natural alterations. For while some plants fermented to produce acids, they generally putrefied like animals. He said that every vegetable, provided it was soft and succulent and put in heaps, would soon generate foul-smelling volatile alkaline salts. Plants acquired a cadaverous taste like putrefied urine and were converted to a greyish pap, just like the gangrene of decayed animals. ${ }^{14}$

So far there seemed to be an agreement that the chemical composition of living matter, whether animal or vegetable, was very similar. A different interpretation however was given by Beccari in a memoir ${ }^{15}$ which described his discovery of gluten, a vegetable protein, in wheat flour. As has recently been pointed out, Beccari seemed strangely unaware of current opinion. ${ }^{16}$

Beccari, a physician who held the chair in medicine, and later in chemistry, at the University of Bologna, was interested in nutrition. He showed that wheat flour contained two different substances, which could be separated by kneading in a current of water. As the water carried away the amylaceous fraction, a tenacious, gluey material remained.

The glutinous component putrefied within a few days like a corpse, emitted a foul odour, and left a black substance which he likened to rotten meat. When the gluey part of wheat flour was distilled, foetid, volatile alkaline products collected in as great a quantity as was extracted from hartshorn.

Beccari might have argued that this further demonstrated the resemblance of plants and animals. Instead he proposed the opposite. Contrary to existing information, he maintained that organic substances fell into two divisions, which corresponded to the two kingdoms, because of their different behaviour in distillation and spon-

12 J. B. M. Bucquet, Introduction à l'Etude des Corps naturels, tirés du Règne végétal, Paris, 1773, 2 vols., vol. 1, p. 422. Bucquet wrote that this term was coined by the 'older chemists'. The name was used by G. F. Rouelle to describe haricots, partly because of the great quantity of volatile alkali which they gave in distillation. He regarded the cruciferous plants as transitional between the plant and animal kingdoms for the same reason. Rhoda Rappaport, 'G. F. Rouelle: an eighteenth-century chemist and teacher', Chymia, 1960, 6, 95.

${ }_{18}$ In 1783-4 a prize was offered by the Société Royale de Médecine for the analysis of cruciferous plants. P. F. Tingry, 'Analyse de quelques plantes cruciferes', Mém. Soc. Roy. de Méd., 1787, 5, $341-414$.

14 Boerhaave (n. 9), vol. 2, pp. 199-203. The fermentation of an organic substance would have been sufficient to indicate its vegetable nature, according to Boerhaave, since he believed that no animal experienced this change, ibid., vol. 2, p. 115. However he thought this process only affected some plants, ibid., vol. 2, p. 202. In another work he made a different statement, remarking that fermentation affected nearly all plants, except a few which putrefied: Dr. Boerhaave's Academical Lectures on the Theory of Physic, London, 1742-6, 6 vols., vol. 1, p. 187.

15 'De Frumento', De Bononiensi Scientiarum et Artium Instituto atque Academia, 1745, 2, part I, 122-27. This was a report of Beccari's discourse. For a translation of the chief passages see Eliot $F$. Beach, 'Beccari of Bologna, the discoverer of vegetable protein', J. Hist. Med., 1961, 16, 354-73.

16 F. R. Jevons, "Boerhaave's teaching in relation to Beccari's identification of gluten as an "animal" substance', J. Hist. Med., 1963, 18, 174-75. 


\section{C. Goodman}

taneous alteration. He stated that natural putrefaction with alkaline products occurred only in animals, never in vegetables, which underwent an acidic fermentation instead. Further animal substances in distillation gave foetid, volatile alkaline extracts, while vegetable substances only yielded acids. Therefore the gluey part of wheat flour was an animal substance, ${ }^{17}$ present in a plant. The other amylaceous part behaved, on the other hand, like a typical vegetable substance.

In this way, ignoring the properties of Cruciferae and vegetable putrefaction, Beccari concluded that in one and the same flour there were two substances of entirely different nature, apparently belonging to two different kingdoms.

Crude generalizations of the type proposed by Beccari were attacked by Venel, a physician who was soon to become professor of chemistry at the University of Montpellier. He remarked: 'It is always surprising to see errors, which a single experiment ought to eradicate, persist and spread'. ${ }^{18}$

He was thinking of the current doctrine that vegetable and animal substances could be distinguished by their distillation products. The prevalence of this false assertion was, he said, particularly strange in view of the analyses carried out earlier in the century by Lémery and other chemists of the Académie des Sciences. He said that their results proved that the appearance of volatile alkali in distillation, far from being an exclusively animal phenomenon, was one of the most common and general results for plants.

Therefore he could not accept Boerhaave's division ${ }^{19}$ of the plant kingdom into those which gave acids predominantly in distillation and others, the cruciferous group, which gave alkalis. Nevertheless he thought the Cruciferae were unusually like animals, because he had extracted a jelly from turnips which seemed exactly like the jelly of animal lymph or hartshorn. So he called Cruciferae 'gelatinous plants' and put them in a separate chemical class. ${ }^{20}$

Venel wrote most of the chemical articles for the Encyclopédie. In one article, ${ }^{21}$ he defined a vegetable substance as any body coming from the vegetable kingdom. He said this could apply to an entire vegetable, its organized parts such as its roots or flowers, its non-organized juices, or any product given by these in chemical art. This last category included volatile alkali, which was therefore a vegetable substance. Precisely the same characteristic, the production of volatile alkali by distillation, would later be used by Berthollet to define an animal substance, a clear indication of the continuing confusion. Volatile alkali was sometimes called 'animal alkali'. ${ }^{22}$

17 This was found in other plants and called 'matière végéto-animale' by $H$. M. Rouelle, 'Expériences chimiques sur le lait, la farine, etc.', J. Méd. Chir., Pharm., 1773, 39, 262.

${ }^{18}$ G.-F. Venel, 'Essai sur l'analyse des végétaux', Mém. Math. Phys. Acad. Sci. Inst. Fr., 1755, 2, 328.

10 Venel said this was a hasty generalization based on the untypical behaviour of woods in distillation, in which very little volatile alkali was liberated, ibid., p. 331. Similarly it was stated that faulty generalizations had been set up describing vegetables as acidescent and animals as alkalescent: E. F. Geoffroy, Traité de la Matière médicale, Paris, 1743-57, 16 vols., vol. 11, p. 23.

20 Venel (n. 18), p. 331.

21 'Végétal (chimie ou analyse végétale)', Encyclopédie, ou Dictionnaire raisonné des Sciences, des Arts et des Métiers, par une Société de Gens de Lettres, Paris 1751-65, 17 vols., vol. 16, pp. 869-71. In the article 'Cendre ou cendres', ibid., vol. 2, pp. 813-14, Venel said that the ashes remaining after the combustion of animals and plants indicated, particularly from their colour, which kingdom they belonged to.

${ }^{21}$ A. Baumé, Chymie expérimentale et raisonée, Paris, 1773, 3 vols., vol. 2, p. 75. 


\section{Application of Chemical Criteria to Biological Classification in the 18th Century}

In addition to conflicting statements of analytical results, there were other difficulties which led the eighteenth-century chemists to be cautious in their conclusions on the constituents of the various kingdoms. There was the old objection that the technique of analysis by fire was faulty on the grounds that this generated new substances not originally in the plant or animal. ${ }^{23}$ Also it was pointed out that the isolation of a material from a member of a particular kingdom did not imply that this material was essential to that kingdom. It might have been accidentally imported from another kingdom. So it was supposed that the phosphorus found in animals was brought by vegetable foods, ${ }^{24}$ and that the common salt obtained in the analysis of organic substances was of extraneous mineral origin. ${ }^{25}$

The same difficulties applied to volatile alkali. It was stated that chemistry was not yet advanced enough to provide the answers, but that a probable hypothesis was that volatile alkali was essential only to animals, the debris of which carried it accidentally into the plant kingdom. ${ }^{26}$

Further developments occurred in the work of Berthollet, who also had a medical training. He said that from the time that he had began to take an interest in chemistry he felt the importance of analytical studies on animal and vegetable substances, since this would give an understanding of nutrition, the chemical action of medicines, and other changes in animals. ${ }^{27}$ This led him to undertake a comparative study of substances from the two kingdoms.

He already inclined to the view that general distinctions could be made, and accepted the crude divisions ${ }^{28}$ of the type made by Beccari. But he was dissatisfied with existing chemical tests, since he said these altered the substances under investigation, and so could only give an imperfect knowledge of their constituents. As Venel and others had proposed before, he thought it would be better to replace dry distillation by tests with solvents, and from these he selected nitric acid. ${ }^{29}$

He studied the effects of nitric acid on silk. He said the reaction produced a fatty substance which no material of vegetable origin gave when similarly treated. ${ }^{30}$ Wool,

${ }^{23}$ This was forcibly expressed in the article 'Végétal', (n. 21), stating that the immediate principles composing plants could only be isolated by the use of various solvents in succession.

${ }^{24}$ Baumé (n. 22), vol. 2, p. 52. The reverse of this, that phosphorus entered plants accidentally from animals, was suggested in 'Acide phosphorique', Encyclopédie méthodique: Chimie, Pharmacie et Metallurgie, Padua, 1786-c. 1807, 6 vols., vol. 1, p. 218. Baumé said that the division of nature into three kingdoms by the natural historian was not recognized as exact by chemists, because vegetables and animals were made up of common chemical principles. He therefore preferred to speak of these collectively as 'organised bodies', ibid., vol. 1, xvi.

${ }_{25}$ P. J. Macquer, 'Kingdoms', A Dictionary of Chemistry, trans. J. Keir, London, 1771, 2 vols., vol. 1, p. 363 . This article also stated that while chemistry could separate the minerals from organic bodies, the differences in the latter were not clear, and that these were due to quantitative variations in constituent principles which were common to plants and animals. See also the articles 'Jelly' and 'Mucilage'. The former was described as the principal animal substance and supposed to be derived from the closely similar vegetable mucilage.

${ }_{26}$ L. B. Guyton de Morveau, H. Maret and J. F. Durande, Elémens de Chymie, théorique et pratique, Dijon, 1777-8, 3 vols., vol. 3, pp. 228-32.

${ }_{27}$ C. L. Berthollet, 'Précis d'observations sur l'analyse animale comparée à l'analyse végétale', Observations sur la Physique, 1786, 28, 272.

28 Ibid.

29 'Avis', J. Méd. Chir. Pharm., 1778, 50, 567. Berthollet was following Bergman, who had treated sugar and other vegetable substances with nitric acid.

so Berthollet, 'Recherches sur la nature des substances animales, et sur leur rapport avec les substances végétales; ou recherches sur l'acide du sucre', Observations sur la Physique, 1785, 27, 88-91. 


\section{C. Goodman}

skin, tendons and hair all gave the same fat or oil with nitric acid. He concluded that this was a distinctive animal characteristic.

But he was more concerned with the gaseous products of the reaction. He thought that Priestley had treated animal substances with nitric acid without an adequate consideration of the source of the gases evolved. Berthollet was convinced from his own experiments that nitrogen was produced in abundance when animal substances were treated with concentrated nitric acid at room temperature, and that the nitrogen was coming from the animal substance, not from the acid. ${ }^{31}$ In support of this he argued that the liberation of the nitrogen preceded the decomposition of the acid. He said that, although in reactions with zinc, nitric acid could be decomposed to nitrogen, this must not be confused with the reaction with animal substances in the cold.

He stated that no vegetable substance behaved in this way. Instead of nitrogen they produced a mixture of fixed air and nitrous gas. Therefore animal substances were distinguished by their constituent nitrogen. This would explain the appearance in their reactions of volatile alkali, the composition of which he had just discovered. In terms of the new nomenclature, which he assisted in formulating, volatile alkali became ammonia, a compound of azote (nitrogen) and hydrogen, the new elements of Lavoisier's chemistry. So when an animal substance was dry distilled or putrefied, Berthollet explained that its nitrogen combined with hydrogen from water to generate ammonia.

Berthollet defined an animal substance as one which gave volatile alkali in distillation. ${ }^{32}$ This included parts of certain plants such as the gluten of wheat and the seed of the mustard plant. Like Beccari, Berthollet regarded these as animal substances which were mixed with the other vegetable parts of the plant.

Apart from nitrogen, Berthollet thought that phosphoric acid was peculiar to animal substances. ${ }^{33} \mathrm{He}$ said this acid was detected in animal charcoals, and accounted for their incombustible nature compared to vegetable charcoals, which were easily burned. He thought that the phosphorus which Marggraf had found in plants must be due to their animal parts. ${ }^{34}$ This was the same logic which he had applied to the source of volatile alkali in the distillation of plants. The effect was to maintain the separation of organic substances into two distinct classes.

The result of Berthollet's work was to establish nitrogen as the characteristic element of animal matter. It also led to the conception that animal substances were

${ }^{81}$ Berthollet, 'Suite des recherches sur la nature des substances animales, et leurs rapports avec les substances végétales', Mém. Acad. Sci., 1785, pp. 331-349.

At the same time Scheele also believed that animal substances had a characteristic reaction with nitric acid; unlike vegetable substances, they gave vitiated air. The Collected Papers of Carl Wilhelm Scheele, trans. L. Dobbin, London, 1931, p. 274.

Berthollet's interpretation of the reaction was opposed by Keir, who thought that the nitrogen originated in the nitric acid, since the other mineral acids extracted none from animal substances. J.[ames] K.[eir], The First Part of a Dictionary of Chemistry, Birmingham, 1789, pp. 205-6.

In fact the nitrogen was produced from nitrogenous organic substances, through a reaction with nitrous acid, generally present in nitric acid. In modern terms, amino-groups of $\alpha$-amino acids, present in plants and animals, react with nitrous acid to produce nitrogen. The nitrogen comes from both the nitrous acid and the organic material.

82 Berthollet (n. 31), p. 333.

28 Ibid., p. 348.

st Ibid. Berthollet argued that the urine of cows and camels was alkaline because these animals fed on plants which contained little animal substance, that is little phosphoric acid. It is true that the urine of vegetarians is alkaline. 


\section{Application of Chemical Criteria to Biological Classification in the 18th Century}

more complicated than vegetable substances. In his early papers, the former contained nitrogen, phosphoric acid, and a peculiar oily principle; the latter contained none of these. Later he weakened these absolute qualitative distinctions, stating that the differences were quantitative: animal substances contained much more nitrogen and much more hydrogen (this formed the oil) than the vegetable class. ${ }^{35}$

Berthollet's views influenced Lavoisier, whose new chemistry interpreted organic substances as compound radicals joined to oxygen. The compound radicals of animal substances contained the elements carbon, hydrogen, azote, phosphorus and sulphur. ${ }^{36}$ Vegetable substances were less complicated, their compound radicals generally consisting of carbon and hydrogen only. He said that these were the true elements of plants, common to all, and that any other elements were peculiar to the particular plants in which they were detected. ${ }^{37}$

This applied to cruciferous plants which contained azote, and others which had phosphorus. He said these approached the complexity of animal substances, but their quantitative composition distinguished them from the animal kingdom, since the two extra elements were present in much smaller quantities. ${ }^{38}$ Although he thought that azote was present in many vegetables, the low content reduced its importance and it failed to qualify in Lavoisier's system as an important element for plants. ${ }^{39}$ It was not difficult to proceed from this position to the false view that trace elements were inessential. ${ }^{40}$

The most elaborate investigation of animal and vegetable substances in the eighteenth century was due to Fourcroy. As a medical student he was interested in the applications of chemistry, which he believed would one day revolutionize medicine. He said that a major research problem for the chemist was a study of animalization, the process by which essential vegetable foods were converted into the parts of the animal body; once this was solved, the animal economy would be fully understood. He thought the best way to approach this would be a comparison of substances from the two kingdoms, discovering their differences and then inquiring into the causes of these differences. ${ }^{41}$

At the start of his research Fourcroy was impressed with a striking analogy between these substances, through his discovery of albumen in plants. ${ }^{42}$ Albumen was well known in eggs as a viscous, white liquid characterized by a remarkable coagulability by heat. Fourcroy now showed that a substance with the same properties ${ }^{43}$ was

os Berthollet, Élémens de l'Art de la Teinture, Paris, 1791, 2 vols., vol. 1, pp. 131-35. Here he indicated how a knowledge of animal and vegetable substances could lead to an understanding of the processes of dyeing wool, silk, cotton and linen.

${ }^{86}$ A. Lavoisier, Elements of Chemistry, trans. Robert Kerr, Edinburgh, 1790, p. 145.

27 Ibid., p. 123.

88 Ibid., pp. 126-27.

so Tartarous acid seemed to be an exceptional vegetable substance since even the quantitative distinctions between the two kingdoms appeared to vanish here. Lavoisier said that experiments indicated that this acid contained azote 'even in considerable quantity'. Ibid., p. 255.

^T This argument was used by Thomas Thomson, 'Animal and vegetable substances', Encyclopaedia Britannica, 3rd ed., supplement, Edinburgh, 1801, 2 vols., vol. 2, p. 570.

$₫$ A. F. de Fourcroy, 'Axiômes chimiques', Encyclopédie Méthodique: Chimie, vol. 2, p. 478.

12 Fourcroy, 'Mémoire sur l'existence de la matière albumineuse dans les végétaux', Ann. Chim., $1789,3,252-62$.

18 He added elsewhere that more experiments were necessary to discover the differences, which he thought must exist between animal and vegetable albumen, in spite of their close analogy. 'Albumine', Encyclopédie Méthodique: Chimie, vol. 2, p. 18. 


\section{C. Goodman}

present in cruciferous plants. When the juices of the horse-radish, cabbage or cress were placed in bottles in a warm water-bath, the familiar white flakes of coagulated albumen were deposited. Like animal albumen it generated ammonia during putrefaction, or when it was distilled. This would explain the peculiar chemical properties of Cruciferae, though he thought that albumen was present in all green plants.

Fourcroy's interpretation of this result was different from that given by Beccari for gluten. He regarded it as a further argument for classifying animals and plants in a single organic kingdom, separate from the inorganic minerals. ${ }^{44}$ The existence of a common albuminous substance was a further example, he said, of the chemical similarity already noticed in vegetable oils and animal fats; vegetable mucilages and animal jellies; gluten and fibrine. It seemed to him that chemistry had confirmed the analogies which anatomists and physiologists had detected in structures and functions.

However Fourcroy soon changed his mind. He wrote that the analogies must not be stressed too much, since animal and vegetable substances showed more differences than resemblances. ${ }^{45}$ This applied to the albuminous, fibrous and mucilaginous substances, the immediate principles ${ }^{46}$ of plants and animals. He said albumen was more abundant in animals. Wheat gluten stretched to many times its original length and imitated a membrane, but he said muscle fibre was more elastic and far more abundant in animals. It was after all reasonable, he said, that the moving parts of animals should be made of a peculiar substance, absent in vegetables which lacked mobility. ${ }^{47}$

But the greatest differences involved the remote principles or elements. He agreed with Berthollet that the principal difference was the much greater quantity of nitrogen in animal substances. This determination was based on his use of Berthollet's nitric acid test. Fourcroy found that most nitrogen was liberated in this way from fibrous muscular matter, albuminous matter gave less and the gelatinous group of animal matters extracted from skin, tendons and cartilage gave least. ${ }^{48} \mathrm{He}$ concluded that gelatinous animal matter ${ }^{49}$ approached vegetable substances, which generally produced little or no nitrogen with nitric acid.

The process of animalization therefore appeared to be due to an increase in the nitrogen content, and Fourcroy considered the sequence gelatine, albumen, fibrine to

${ }^{44}$ Fourcroy (n. 42), 3, 253-54.

${ }^{45}$ Fourcroy, 'Matières animales', Encyclopédie Méthodique: Chimie, vol. 4, pp. 316f. and Élémens d'Histoire naturelle et de Chimie, 4th ed., Paris, 1791, 5 vols., vol. 4, pp. 481-88.

${ }^{46}$ So called, Fourcroy said, from the immediate, almost mechanical type of analysis employed to extract them in their original state. They were in turn composed of the remote principles or the elements. Fourcroy, 'Axiốmes chimiques' (n. 41), p. 474.

${ }^{47}$ Fourcroy, Élémens (n. 45), vol. 4, p. 484. The relation between function and chemical composition was also referred to by Fourcroy in his analysis of the pollen of the date-palm. The pollen smelt like semen and reacted chemically like an animal substance. He concluded that their common function in reproduction was due to their similar composition. Fourcroy, 'Recherches chimiques sur le pollen, ou la poussière fécondante du dattier d'Egypte, Phoenix dactylifera', Ann. Mus. Hist. Nat., 1802, 1, 417-38.

48 Fourcroy, 'Extrait d'un mémoire ayant pour titre: recherches pour servir à l'histoire du gaz azote ou de la mofette, comme principe des matières animales', Ann. Chim., 1789, 1, 40-46.

${ }^{40}$ Fourcroy, 'Gélatine', Encyclopédie Méthodique: Chimie, vol. 4, 72-73. This also concerned the comparison of the blood of the foetus and adult, which Fourcroy felt was an important subject. He thought there was a comparative abundance of gelatine in the foetus, which seemed to indicate a preliminary degree of animalization. The adult had more fibrine, regarded by Fourcroy as the final stage of animalization. Fourcroy, 'Chimie', Encyclopédie Méthodique: Chimie, vol. 3, p. 627. Compare Bonnet's remark that the foetus was in a vegetating state. C. Bonnet, Oeuvres d'Histoire naturelle et de Philosophie, Neuchatel, 1779-83, 8 vols., vol. 3, p. 66. 


\section{Application of Chemical Criteria to Biological Classification in the 18th Century}

represent an increasing scale of animalization. The removal of nitrogen from these animal matters should convert them to their original vegetable state, and he thought this was shown in the formation of vegetable oxalic acid in their reactions with nitric acid. Conversely the addition of nitrogen to vegetable substances should cause their animalization, ${ }^{50}$ and the mechanism of this would lead to a better understanding of the animal economy.

But animalization was more than a simple addition of nitrogen. Fourcroy said the process also involved changes in the quantities of other elements. ${ }^{51}$ Phosphorus was abundant in animals; Scheele had found phosphates in bone, and Fourcroy had isolated them from urinary calculi. Plants contained less phosphorus, and he suspected that this was not essential to them, but was merely a foreign ingredient taken from the earth by their roots. ${ }^{52}$ The same remarks applied to the role of sulphur in the two kingdoms.

He agreed with Berthollet that there was much more hydrogen in animals, since their materials in distillation gave more water and oil than plants. He added that there was less carbon in animals, since, compared to plants, less carbon dioxide was produced in dry distillation. In fact, he said: 'Carbon in animals plays nothing like the role it has in the vegetable economy'. ${ }^{53}$

For while carbon accumulated in plants, it escaped continuously in the respiration of animals; it was a transitory, unimportant element for animals.

Fourcroy concluded that animal substances had a more complicated composition than vegetables. He conceived of plants as chemical instruments which began the organization of crude inorganic matter, synthesizing this into food for animals. ${ }^{54}$ He said they were intermediates in the scale of being, between minerals and animals. The general result of this synthesis was a compound of carbon, hydrogen and oxygen, and sometimes a little nitrogen. But here the place of nitrogen in the plant kingdom was not clearly delineated; its importance, which does not depend on its quantitative presence, was not yet understood. Sometimes Fourcroy referred to nitrogen, together with phosphorus and sulphur, as an inessential accessory; ${ }^{55}$ elsewhere he resorted to the imprecise statement that plants were made up of three or four elements. ${ }^{56}$ On the other hand the more elaborate animal substances were at least quaternary compounds of carbon, hydrogen, oxygen and much nitrogen, and besides these there were variable quantities of phosphorus and sulphur.

The emphasis was on the quantitative differences of the elements. Fourcroy believed these caused marked variations in chemical properties, which permitted the character-

${ }^{\text {so }}$ Fourcroy (n. 41), vol. 2, pp. 480-81.

\$1 Fourcroy, 'Matières animales' (n. 45), pp. 317-18.

${ }^{32}$ Fourcroy, Systeme des Connaissances chimiques, Paris, 1801-2, 11 vols., vol. 8, pp. 101f. The presence of phosphorus in onions was attributed to the animal matter used to grow them: Fourcroy and L. N. Vauquelin, 'Mémoire sur l'analyse chimique de l'oignon', Ann. Chim., 1808, 65, 172-73.

${ }^{58}$ Fourcroy, 'Carbone', Encyclopédie Méthodique: Chimie, vol. 3, p. 64.

s4 Fourcroy, Systeme (n. 52), vol. 8, p. 257.

ss Ibid., vol. 7, p. 57.

${ }^{56}$ Fourcroy (n. 41), vol. 2, p. 477. The influence of these ideas can be traced in Cuvier's thought. Cuvier considered that the possession of more functions in animals compared to plants, as in mobility and sensation, required a more complicated chemical composition. Therefore animals contained the extra element nitrogen, which was only present in plants by accident. Like Fourcroy he thought animals got rid of their excess carbon by respiration, while their nitrogen accumulated. G. Cuvier, Le Regne animal, 2nd ed., Paris, 1829-30, 5 vols., vol. 1, pp. 18-21.

C 


\section{C. Goodman}

ization of an organic substance as animal or vegetable. He remarked that there was now a much larger number of distinguishing tests, and he proceeded to describe these in greater detail than had been attempted before. ${ }^{57}$

The action of heat was a well-established distinguishing test, but he said it was not before understood. The phenomena were quite different for animal substances because of their more complicated composition. Animal liquids tended to coagulate; animal solids emitted abundant vapours with the familiar foul odour, due to hydrogen, compounds of nitrogen, phosphorus and sulphur. During their thermal decomposition, animal solids exhibited a twisting and agitation, which Fourcroy interpreted as an indication of irritability and resistance to destruction. This produced an animal charcoal, denser, more adherent, and in smaller quantity than vegetable charcoal. Above all, animal charcoal was much more difficult to burn to an ash, because of the abundance of phosphates, and the smaller quantity of carbon. Therefore in contrast to the easy conversion of wood to ashes, hours of strong heat with agitation were required to incinerate blood or muscle. ${ }^{58}$ The prime animal characteristic of plentiful nitrogen was clearly indicated in distillation, as Berthollet had already said, in the formation of ammoniacal products such as the crystalline carbonate of ammonia.

Fourcroy thought that animals putrefied in a distinctive manner. Their decay was more rapid and more marked than plants. He explained that this was another consequence of elaborate composition. The presence of more elements in greater quantities in animal compounds created multiple attractions which made them less stable. The slightest changes in temperature and moisture were sufficient to destroy the equilibrium and decompose the animal substance into simpler volatile compounds of hydrogen with nitrogen, phosphorus and sulphur; these produced the insupportable odour.

A new distinguishing test proposed by Fourcroy was the reaction with water. $\mathrm{He}$ said the effect of warm water on animal solids was most familiar in the cooking of meat, which through changes in colour, taste, smell and hardness became edible. The cooking of vegetables produced smaller changes, and besides they could be eaten raw. The differences were more striking still after a prolonged digestion in water. Most animal matter was then converted to a fatty substance like spermacetti, and ammonia was generated; but vegetables blackened and carbonized. He said the process of cooking was not understood, but he attributed the differences to the greater amounts of hydrogen and nitrogen, and the lower carbon content of animal substances.

Finally Fourcroy described the reactions of animal compounds with acids and alkalies. Again he supposed that the peculiar effects, not shown by vegetables, were due to a more complicated composition. Sulphuric acid decomposed animal substances, producing a peculiar fat and generating ammonia. Nitric acid turned animal compounds yellow, liberated much nitrogen, produced a peculiar fat and prussic acid. ${ }^{59} \mathrm{He}$ thought that alkalis acted more powerfully on animal substances, which

57 Fourcroy, 'Matières animales', (n. 45), pp. 318-43. p. 123.

68 For further details see Fourcroy's article 'Cendres', Encyclopédie Méthodique: Chimie, vol. 3,

so Fourcroy thought that prussic acid was one of the most distinctive products of reactions with animal substances. But soon it was to be described as one of the immediate principles of plants, present in bitter almonds, prunes and other fruits. Vauquelin, 'Expériences qui démonstrent la présence de l'acide prussique tout formé dans quelques substances végétales', Ann. Chim., 1802-3, 45, 206-12. 


\section{Application of Chemical Criteria to Biological Classification in the 18th Century}

soon softened. This explained the medical use of caustic alkali in the treatment of tumours. On the other hand vegetable tissues were little affected.

These tests did not carry the specificity which Fourcroy claimed. They were insufficient to identify animal substances uniquely, since various vegetable materials behaved in the same way, as Fourcroy himself knew. In his description of the distillation of animal substances he said that the formation of particles of ammonium carbonate had long been recognized as a characteristic product of this operation; but he was forced to add that the same phenomenon occurred in the distillation of vegetable extracts, Cruciferae, and mushrooms. ${ }^{80}$

The tests were particularly inadequate for gluten, which Fourcroy regarded as vegetable. He said it was 'like no other vegetable matter'. ${ }^{61}$ A tenacious, fibrous material with an odour, which he likened to sperm, it was found by Fourcroy to have a remarkable conformity with animal substances in its chemical reactions. He had to admit that in a strong fire it behaved just like an animal fibre, swelling, moving and burning like feather or horn, and emitting a foetid odour. In dry distillation gluten produced much ammonium carbonate and some prussic acid. The disagreeable smell was exactly like that accompanying animal distillations, and he said this could lead one to confuse them. The residual charcoal, like those of animal origin, was difficult to incinerate. Further striking analogies with animal materials were exhibited in its identical mode of putrefaction in warm, moist air and in its reaction with nitric acid.

Additional conflicting instances occurred in the albuminous substances, which Fourcroy had found widespread in the plant kingdom. He had searched in vain for chemical tests which would distinguish these from animal albumen. He said vaguely that albumen was more abundant in animals, but it soon became apparent through the work of Vauquelin, his student and colleague, that not even this quantitative distinction could be rigidly maintained.

Vauquelin investigated the milky juice of the Carica papaya or tropical pawpaw, ${ }^{62}$ which interested him on account of its medical employment as an anthelmintic. The results astonished him. The dried juice in water putrefied with an animal odour and deposited white flakes. When heated the flakes crackled like roasted flesh, and fat droplets appeared; no residue remained. From the reactions of the juice with acids, its behaviour in distillation, and its coagulation by heat, Vauquelin concluded that the pawpaw contained a substance which was most like albumen. He thought the juice also contained a little fibrine and much phosphate; it seemed to differ from blood only in the absence of a colouring ingredient. He remarked: 'This teaches us that nature has also given to certain types of plants the faculty of forming compounds similar to those produced in the animal machine, which must however put us on our guard when it is a question of pronouncing if a material belongs to vegetables or animals., ${ }^{63}$

There was nothing unusual in the mere presence of an albuminous substance in the pawpaw, since, as Fourcroy had shown, many plant juices contained this; but he

${ }^{00}$ Fourcroy, 'Matières animales (n. 45), p. 320.

'1 Fourcroy, 'Gluten ou Glutineux', Encyclopédie Méthodique: Chimie, vol. 4, p. 81, and Elémens (n. 45), vol. 4, pp. 177-81.

62 Vauquelin, 'Examen chimique du suc de papayer', Ann. Chim., 1802, 43, 267-75 and 'Analyse du suc papayer (Carica papay.)', Ann. Chim., 1803-4, 49, 295-305. This plant contains the nitrogenous enzyme papain.

Gauquelin, 'Examen chimique du suc de papayer' (n. 62), p. 274. 


\section{C. Goodman}

added: 'What is surprising is . . . the abundance and its purity in the pawpaw, in which one finds nothing having the properties of vegetables; and if this substance was coloured like the albumen of the blood ... one could easily confuse the one with the other.' 64

Here was a complete plant juice behaving exactly like an animal substance. Vauquelin also found much nitrogenous matter in the Salsola, ${ }^{65}$ tobacco $^{66}$ and belladonna. ${ }^{67}$ His analyses opposed Fourcroy's chemical separation of animal and vegetable substances, and his conclusions approached the opinion expressed earlier in the eighteenth century that the chemical analogies of the two kingdoms were more impressive than their differences. The latter could not be stated with precision; the exceptions prevented the establishment of two mutually exclusive classes.

\section{APPLICATIONS IN BIOLOGICAL CLASSIFICATION}

In the eighteenth century there were two principal areas in which chemical evidence was employed for the purposes of establishing the place of ambiguous organisms in the scale of nature. The biological groups concerned were the cryptogamia and the zoophytes, an Aristotelian designation referring to living forms which appeared to have properties in common with both animals and plants, and which comprised a heterogenous group, whose classes were not distinguished until the nineteenth century.

Amongst the cryptogamia there were certain algae with properties which surprised even those who were most inclined to accept them as plants. The Oscillatoria was found to have the animal faculty of independent motion. The texture of various algae was membranous and likened to the vesicles of the lungs ${ }^{68}$ or the tissue of the peritoneum $;^{69}$ they were also gelatinous, and one type so resembled frog-spawn that it was called Batrachosperma. ${ }^{70}$

In the middle of the century descriptions ${ }^{21}$ were given of the green algae which collected in the warm waters of spas, and they were classified as plants; but this later became a matter for argument. An Austrian physician ${ }^{\mathbf{7 2}}$ reported that he had seen signs of animal movement in the green creature found in the waters at Carlsbad. He was therefore inclined to transfer it from the plant to the animal kingdom, and he supported this proposal with the results of a chemical analysis. The distillation of the green substance produced volatile alkaline salt; the residue was phosphorescent and contained no potash. He regarded these products as typically animal. It represented

ot Vauquelin, 'Analyse du suc papayer' (n. 62), pp. 304-5.

os Vauquelin, 'Analyse du Salsola Soda de Linnéus', Ann. Chim., 1793, 18, 65-81.

-6 Vauquelin, 'Analyse de deux variétés de tabac, nicotiana tabacum latifolia et angustifolia', Ann. Mus. Hist. Nat., 1809, 13, $254-66$.

67 Vauquelin, 'Analyse de la belladone', Ann. Chim., 1809, 72, 53-68. See also Fourcroy and Vauquelin, 'Mémoire pour servir à l'histoire chimique de la germination et de la fermentation des graines et des farines', Ann. Mus. Hist. Nat., 1806, 7, 1-18. In this study, which began in 1800, they reported the presence of much animal matterin barley and marsh plants. They said this explained why they could be employed in nutrition as a substitute for meat.

os J. B. de Secondat, Observations de Physique et d'Histoire naturelle sur les Eaux minerales, Paris, 1750, pp. 12-13.

${ }_{00}^{\circ} \mathrm{G}$. K. Springsfeld, 'Observation physique sur une plante assez particulière qui crôit aux environs des eaux chaudes de Carlsbad en Boheme', Histoire de l'Académie Royale des Sciences et Belles Lettres, Berlin, 1752, p. 104.

${ }_{70}$ F. W. Weiss, Plantae Cryptogamicae Florae Gottingensis, Göttingen, 1770, p. 33.

71 Secondat (n. 68), and Springsfeld (n. 69).

72 J. A. Scherer, 'Beobachtungen und Versuche über das pflanzenähnliche Wesen in den warmen Carlsbader und Töplitzer Wässern in Böhmen', Abh. Böhmisch. Ges. Wiss., 1786, 2, 254-71. 


\section{Application of Chemical Criteria to Biological Classification in the 18th Century}

an application of the current crude generalization which described volatile alkali as an exclusively animal product.

A similar argument with the opposite conclusion was employed by Georgi, ${ }^{73}$ a German pharmacist who became a professor of chemistry at St. Petersburg. He thought that chemistry could decide the status of the ambiguous algae, on the grounds that most plants behaved differently from most animals in distillation and alteration. Ignoring the exceptions, he applied this generalization to the Confervae. He heated some specimens and obtained resins which gave a pleasant smell in burning; he detected no foul animal odours. He distilled Confervae in a retort and collected an acidic phlegm; but no ammoniacal salts, and barely a trace of volatile alkali. The residue was easy to calcine and produced an abundant ash. He concluded that analysis had shown the Confervae to be of a vegetable nature, not containing anything animal.

A series of chemical tests on the algae were next performed as a result of Priestley's description of green matter, which he was surprised to find on the inside of phials of water, in which he had been studying the growth of sprigs of mint. ${ }^{74} \mathrm{He}$ doubted that the green matter was a plant, since it seemed to have no form. Moreover it appeared abundantly even in tightly corked vessels of water, so that seeds or animalcules floating in the air could not be the cause. Therefore he said that green matter was neither animal nor vegetable, but 'a thing sui generis'. He had observed bubbles of the pure air which plants generated in water, but at first he thought these were coming from the water itself, not from the green matter. He corrected this after he was convinced by the microscopic studies of some friends that green matter was after all a plant. He thought it was a conferva, and called it 'water moss'.

It is interesting that the purification of the air was not regarded as an exclusive property of plants. Fontana ${ }^{75}$ said botanists had been deceived by the green organisms found in stagnant water. They were animals since they were oviform and in motion. The dephlogisticated air which they produced simply showed that animals as well as plants could prepare this gas.

This influenced Ingenhousz, who had originally regarded Priestley's green matter as a plant, ${ }^{76}$ since his own experiments in photosynthesis had shown that all green plants in sunlight emitted dephlogisticated air. He studied the organism every day for more than three years, but still he confessed that its behaviour baffled him. The microscope showed a series of transformations. At first the greenish particles were round and clearly moving, so he had no doubt they were insects. Then these became imprisoned in a gelatinous crust, which he said was the state in which Priestley had observed the organism. Some weeks later the crust was found to have transparent fibres, which had a propagating motion like a worm. Ingenhousz collected dephlogisticated air throughout these changes, but agreed with Fontana that the production of this air was no proof of the vegetability of an organism. ${ }^{77}$ It seemed to him that green matter in its

${ }^{73}$ I. G. Georgi, 'De Confervae Natura, Disquisitio Chemica', Acta Acad. Sci. imp. Petropolit., 1778, pp. 225-33.

${ }^{74} \mathrm{~J}$. Priestley, Experiments and Observations relating to various branches of Natural Philosophy, London, 1779-1786, 3 vols., vol. 1, pp. 338-44 and vol. 2, pp. 16 and 32.

${ }_{75}$ F. Fontana, 'Lettera sopra la Fisica', Memorie Mat. Fis. Soc. ital. Sci., 1782, 1, 704-5.

${ }_{70} \mathrm{~J}$. Ingenhousz, Nouvelles Expériences et Observations sur divers Objets de Physique, 2 vols., Paris, 1785-9, vol. 3, p. 10.

77 Ibid., vol. 2, pp. 51 and $93 f$. 


\section{C. Goodman}

changes alternated between the animal and vegetable kingdoms. ${ }^{78}$ Further, he said the debris of green matter generated the filamentous Conferva rivularis of water reservoirs and the Tremella nostoc. He therefore thought the vegetability of these two species was now also in doubt. ${ }^{79} \mathrm{He}$ conjectured that the insects of green matter had formed them. The filaments of this conferva also contained round corpuscles, which when released by cutting the filaments acquired motion within a few days. He said this showed they were insects full of life. It seemed to be a zoophyte, like coral.

Ingenhousz was already convinced from the appearance of motion that Priestley's green matter had to be put in the animal kingdom. He then turned to chemical analysis for confirmation of his conclusion; but he remarked: ‘. . only a weak argument can be drawn from chemical analysis, a fallible conjecture, in judging if a substance is animal or vegetable.' ${ }^{\prime} 0$

This was because the products of distillation were not peculiar to a particular kingdom. Nearly all animal substances gave an alkaline principle; plants sometimes gave acids and sometimes, as in the Cruciferae, volatile alkali. Without giving the details he said that green matter, the Conferva rivularis and the Tremella nostoc all behaved like animal substances, presumably in distillation; but he insisted: '. . I I repeat this analysis alone could not serve as a demonstration'. ${ }^{81}$

Chemistry played a more important role in Senebier's discussion of Priestley's green matter. He thought that analysis was still imperfect since it generated products not originally in the specimen. Nevertheless it provided useful information and he was optimistic that future improvements would assist plant physiology. He particularly wanted a rigorous chemical analysis of aquatic and cryptogamous plants. ${ }^{82}$

His chemical experiments were assisted by Tingry, his teacher and professor of chemistry at Geneva. ${ }^{83}$ Senebier distilled green matter ${ }^{84}$ and collected an ammoniacal liquor; the abundant charcoal was calcined to an ash which contained potash. Alcohol extracted a typically vegetable resin. It was true, he commented, that green matter had given ammonia by distillation, but so did the Cruciferae, and no one suspected that these were animal. Besides he continued: 'It is possible that this ammonia is due to the debris of numerous animalcules, flies and butterflies which have perished in the green matter'.85

He said that if he had not solved the problem, this was the path to follow. The results of the analysis, together with the production of oxygen and the loss of green colour in the dark, showed, he said, that green matter was a true plant, a species of conferva.

At the end of the century the animality of Confervae was again proposed in a joint

78 Ibid., vol. 2, pp. 9-10. ${ }^{70}$ Ibid., vol. 2, pp. 102f. ${ }^{80}$ Ibid., vol. 2, p. 120.

${ }^{81}$ Ibid. Ingenhousz's observations were said to throw new light on the passage from the vegetable to the animal kingdom. J. H. Hassenfratz, 'Extrait du troisième volume des nouvelles expériences de M. Ingen-Housz', Ann. Chim., 1789, 3, 272.

${ }_{82}$ J. Senebier, Physiologie végétale, Geneva, 1800, 5 vols., vol. 5, p. 238. In vol. 5, p. 198, he referred to Berthollet's work.

${ }_{83}$ Senebier, Mémoires Physico-Chymiques ..., Geneva, 1782, 3 vols., vol. 2, p. 160.

84 Senebier, 'Huitième mémoire sur la matière verte ...', J. Phys., 1799, 49, 213-19.

ss Ibid., p. 219. He also made use of the common distinction relating to the quantities of ammonia involved. He said Confervae gave only a little ammonia, while the animal corallines, which some had compared them to, gave much: 'Sur les conferves considerées dans leur propriété de donner du gaz oxigène, quand elles sont exposées sous l'eau au soleil', J. Phys., 1799, 49, 368. 


\section{Application of Chemical Criteria to Biological Classification in the 18th Century}

study ${ }^{88}$ by Girod-Chantran, a naturalist, and Lacroix, the renowned mathematician. This involved a combination of observations with the microscope and numerous chemical tests, in which the influence of Berthollet and Fourcroy is apparent. The nitric acid test was applied to the Conferva bullosa; it gave azote. With a byssus, nitric acid produced the yellow coloration that Berthollet had noticed with silk. Digestion of Confervae in water was tried; one specimen became more viscous, another putrefied with an ammoniacal odour. The conferva was heated with caustic soda; ammonia was liberated. Various Confervae, Byssus and Tremella were distilled or heated in air; animal odours were observed, ammoniacal products collected and the ashes examined. The co-workers stressed the large quantities of the latter, their difficult incineration, their large lime content, and occasionally their complete absence of vegetable potash.

These observations convinced Girod-Chantran that these organisms had been 'usurped by botanists'. ${ }^{87} \mathrm{He}$ wrote: '... all these considerations show that the time is not far off when these aqueous products, not having any type of fruit, till now classed with the plants, will rise in the scale of being, and be placed with the polyps, above the plants' ${ }^{88}$

The Société Philomathique requested Vauquelin and others to repeat these chemical experiments. It was stated that the commissioners confirmed the results, and made some additions. ${ }^{89}$ According to deCandolle, who was also asked by the Société to evaluate this research, Vauquelin came to the opposite conclusion, that the specimens were vegetable. ${ }^{00}$ The importance of chemistry in reaching a decision was particularly emphasized by Decandolle: 'Let us see if the older view of Confervae as plants is more admissible than this of their animality. The examination of their chemical nature and of their mode of life and structure must resolve this question'.91

Referring to Vauquelin's analyses, he said that Confervae gave very little ammonia in distillation. Also Giron-Chantran and Lacroix had mistaken potash in the ashes for soda. Finally the large quantity of the ashes proved, not their animality, as these workers suggested, but on the contrary their vegetability, as indeed Fourcroy had maintained. Decandolle therefore rejected their animality or intermediate nature and pronounced them true plants and put them with the algae.

However the animal nature of algae continued to be asserted. Blumenbach ${ }^{\mathbf{2}}$ put Priestley's green matter with the infusoria in Chaos, the Linnaean group of lowest animals. Bory de Saint Vincent, ${ }^{93}$ a botanist, was impressed with the similarity of Confervae to animals, indicated by his chemical tests. He found that the Thorea putrefied

86 J. Girod-Chantran and S. F. Lacroix, 'Extrait d'un mémoire sur l'analyse chimique des conferves', Bull. Sci. Soc. Philomath., 1791, pp. 59-60. See also the chemical tests in Girod-Chantran, 'Observations microscopiques sur les plantes cryptogames', Bull. Sci. Soc. Philomath., 1797, p. 43, and Girod-Chantran, Recherches chimiques et microscopiques sur les Conferves, Bisses, Tremelles, etc., Paris, 1802.

${ }^{87}$ Girod-Chantran, Recherches chimiques (n. 86), p. $239 .{ }^{88}$ Ibid., p. 7.

${ }^{80}$ Girod-Chantran and Lacroix, 'Extrait d'un mémoire' (n. 86), p. 59.

20 A. P. Decandolle, 'Rapport sur les conferves', J. Phys., 1802, 54, 427. A similar statement is found in Girod-Chantran, Recherches chimiques (n. 86), p. 1 .

-1 Decandolle (n. 90), p. 427. A different opinion was given by Vaucher in his classical study of these algae. Their mode of reproduction persuaded him that they were plants. Chemistry, however, could not determine their kingdom, because he reflected: 'Has not the Creator been able to vary in different creatures not only the proportions, but also the constituents of their compounds, without altering the nature of the organism?' J. P. Vaucher, Histoire des Conferves d'Eau douce, Geneva, p. 142.

98 J. F. Blumenbach, Manuel d'Histoire naturelle, trans. S. Artaud, Metz, 1803, 2 vols., vol. 2, p. 101.

's J. Bory de Saint-Vincent, 'Mémoire sur un genre nouveau de la cryptogamie aquatique, nommé thorea', Ann. Mus. Hist. Nat., 1808, 12, 126-35. 


\section{C. Goodman}

with an animal odour, which he compared to rotten oysters. Nitric acid produced prussic acid, which Fourcroy had mentioned as an animal characteristic. Its behaviour in distillation also convinced Bory that this species was remarkably animalized.

The continual transfer of the algae from one kingdom to another indicated the difficulties which these organisms present in classification. It also showed that the chemical tests were inconclusive. The varying interpretations which were given, particularly to the detection of ammonia, revealed the uncertainties concerning nitrogenous matter in the plant kingdom.

The same difficulties arose with the fungi, which in the eighteenth century were candidates for all three kingdoms. ${ }^{94}$ Mushrooms were without flowers, leaves or roots, and apparently without seeds. They fed on decaying matter and grew at a remarkable rate. Their texture was compared to flesh or muscle. Their infusions in water appeared to some observers to contain moving insects. These peculiarities led to their exclusion from all the kingdoms and the creation of a special kingdom to contain them. Necker ${ }^{95}$ called this the 'Regnum mesymale' or intermediate kingdom, placed between plants and minerals. Willemet ${ }^{96}$ suggested a new class of 'Pseudo-zoo-lithophytes'.

Mushrooms were also known to have peculiar chemical properties. ${ }^{97}$ The analyses had medical interest, since the causes of mushroom poisoning were sought, as were reliable means for distinguishing noxious and nutritious species. In distillation Lémery ${ }^{98}$ reported surprising quantities of ammoniacal products, and said this could confuse mushrooms with animals. The analysis of fungi was often described as animal. The mushroom was said to be more alkalescent than any other plant and likened to animal food. ${ }^{99}$ Nitrogenous substances compared to albumen and gluten were extracted from mushrooms, and the accompanying odours likened to fish or burning horn. ${ }^{100}$

Bouillon-Lagrange ${ }^{101}$ analysed truffles and mushrooms, employing tests suggested by Berthollet and Fourcroy. Nitric acid turned the truffle yellowish and nitrogen was liberated. He commented that this distinguished it from vegetables. In water the truffle exhibited a filamentous texture, which he compared to animals. When the water was heated, a flocculent precipitate appeared, due to the coagulation of albumen. He left a paste made with truffles and water in the air; after a few days this decayed with an odour like cheese, and much ammonia was produced. Distilled truffles left a residue that was difficult to incinerate and contained phosphoric acid. Mushrooms gave the same results. On the basis of these chemical experiments Bouillon-Lagrange concluded: '. . . the truffles must be distinguished from vegetables and form a special class under the title of Animalized plants.' ${ }^{102}$

a4 For a review of the opinions held see P. R. Willemet, 'Essai sur l'histoire naturelle du champignon vulgaire', Nouv. Mém. Acad. Dijon, 1784, 2, 195-211.

of N. J. de Necker, Traité sur la Mycitologie, Mannheim, 1783, p. 103.

o6 Willemet (n. 94), p. 211.

97 Fungi contain chitin, a nitrogenous substance which also forms the integument of insects and crustacea.

oo 'Agaricus or mushroom', Encyclopaedia Britannica, 3rd ed., Edinburgh, 1797, vol. 1, p. 231.

$100 \mathrm{H}$. Kind, 'Chemische Úntersuchung des gepfefferten Fleischschwammes (Agaricus piperatus)', J. Pharm., 1797, 4, 124-40; I. L. Jordan, Disquisitio chemica evictorum Regni Animalis ac Vegetabilis Elementorum, Göttingen, 1799, pp. 74-75.

${ }^{101}$ E. Bouillon-Lagrange, 'Examen chimique de la truffe Lycoperdon, Tuber, Linn.', Ann. Chim., 1803, 46, 191-212.

${ }_{102}$ Ibid., p. 212. The same conclusion appeared in his 'Analyse de deux especes d'agaric, le boletus larix et le boletus igniarius (Lin.)', Ann. Chim., 1804, 51, 75-96. 


\section{Application of Chemical Criteria to Biological Classification in the 18th Century}

Apart from the fungi and algae, the zoophytes continued to present problems in classification for the eighteenth century, and here the introduction of chemical arguments was most apparent. The group consisted of sponges, gorgonians (invertebrates with branching forms remarkably like vegetation, as in the sea-whip, sea-fan, sea-willow and sea-plume), corals, and the so-called corallines, a confused class which included coelamate and coelenterate invertebrates and also calciferous algae. They were variously described as spongey, stony, horny and ligneous.

At the beginning of the century Tournefort regarded these as marine plants and put them in a class with the algae and fungi. ${ }^{103}$ Their evident porous texture was seen by him to indicate the mode of nutrition. He said that when the branches of some specimens were lit, they burned with a smell of horn or birds' feathers and left little residue, which led him to conclude that volatile ammoniacal salts were present. ${ }^{104}$ There was no question here of considering animality. Tournefort had already decided that corals and corallines were plants, and his description of the combustion phenomena simply implied that animals and plants were chemically alike, as the chemists were then asserting.

The same was true of Marsigli's discussion. He relied on chemistry to establish that stony corals and madrepores were really organic and not petrifications. His famous observation of expanding and contracting forms in coral, fresh from the sea, had convinced him that he had seen the flowers of the coral plant. He added: 'Chemical analysis also shows us in an indisputable manner that these stony vegetations really are plants; when fresh the same constituents can be extracted from them as from terrestrial plants and animals.' ${ }^{105}$

The importance of chemical evidence for this natural historian was apparent in his simple statement that: 'Chemical analysis must terminate the question so often asked, that is, if coral is or is not a plant.' ${ }^{106}$

He distilled fresh coral and obtained alkaline liquors, pungent ammoniacal products and bituminous deposits. He made no remark that any of these products was peculiarly animal. Instead he compared the analysis with that of another specimen of coral, which had been out of the sea for over a year. The distillation of this no longer gave alkaline phlegm or bitumen, and he concluded that this was typical of marine plants, which lost their constituents when they were taken away from their food source in the sea. ${ }^{107}$ That it did not occur to Marsigli to try to distinguish between animals and plants seems to show that he was following the view of Homberg and

${ }_{103} \mathrm{~J}$. Pitton de Tournefort, Institutiones Rei Herbariae, 3 vols., Paris, 1700, vol. 1, pp. 550-77.

${ }^{104}$ Tournefort, 'Observations sur les plantes qui naissent dans le fond de la mer', Mém. Acad. Sci., 1700 , pp. 27-36. Similarly the extraction of large quantities of urinous volatile substances from stony marine organisms and sponges did not prevent Geoffroy from regarding these as plants. E. F. Geoffroy, 'Analyse chimique de l'éponge de la moyenne espece', Mém. Acad. Sci., 1706, pp. 507-8.

${ }_{105}$ L. F. Comte de Marsigli, Histoire physique de la Mer, Amsterdam, 1725, p. 107.

106 Ibid., p. 131. He thought the analysis of coral could lead to medical applications. He looked to Homberg to guide his experiments: Marsigli, 'Mémoire sur les fleurs du corail', J. Sçavans, 1707, 36, 302-10.

${ }_{107}$ Ibid., pp. 131-34. Marsigli sent the Académie Royale des Sciences flakes of various corals and some of their distillation products for further examination. This was undertaken by Geoffroy, whose conclusions agreed with Marsigli: E. F. Geoffroy, 'Observations sur les analyses du corail et de quelques autres plantes pierreuses, faites par M. le Comte Marsigli', Mém. Acad. Sci., 1708, pp. 102-5. Later in the century it was pointed out that Marsigli's results could not have led to the conclusion that corals were animal, since chemistry showed that the Cruciferae also gave ammoniacal distillation products. J. E. Guettard, Mémoires sur différentes Parties des Sciences et Arts, Paris, 1768-83, 5 vols., vol. 2 , p. 44. 


\section{C. Goodman}

Lémery that chemically there was a single organic kingdom, distinguishable from the minerals. His analysis of the sponge confirms this; he saw nothing to conflict with his belief that the sponge was a plant from the large quantities of ammoniacal salts which appeared during distillation. ${ }^{108}$

A different interpretation of the chemical analysis of marine zoophytes was soon proposed by Peyssonnel, a physician and botanist, who consequently classified sponges, corals and madrepores as animals. ${ }^{109} \mathrm{He}$ regarded the milky juice of coral as the blood of the insects which produced it. The smell of rotten fish in the putrefaction of coral was caused by the death of the insects. He supposed the insects were housed in the bark, and believed this was confirmed by distillation, which exhibited the same oils, phlegms and salts as were extracted from human skull, hartshorn and other animal parts.

More consideration was given to the theory that coral was made by insects after Trembley's discovery of the water polyp in 1739. It was then confirmed by the microscope that what Marsigli had taken to be flowers in coral were actually the tentacles of polyps.

Attention then turned to the corallines and gorgonians. The natural historian who was most widely credited with the demonstration of their animality was John Ellis, who based his arguments on observations with the microscope, and especially on chemical evidence.

Ellis said that the gorgonians such as the sea-fan were like shrubs with roots, stems and a network of branches. Their forms had misled many into regarding them as plants, a conclusion which he said was falsified by chemical analysis: 'The chemical Experiments, that have been made on these Bodies are a strong Proof, if there were no other Demonstrations, of their being animal. I need not mention any other to the curious, than the great Quantity of volatile Salts, that may be extracted from them and the strong Smell they yield, when burnt, of roasted Oysters.'110

Ellis could not accept an intermediate nature for these organisms, which Linnaeus supposed in classifying them as zoophytes. Ellis therefore wrote to Linnaeus insisting that any suggestion of vegetability in the stem of gorgonians was excluded on chemical grounds. 111

Similarly Ellis said that chemistry showed that the sponge was an animal. ${ }^{112} \mathrm{He}$ was particularly concerned with establishing the true nature of the corallines, which like corals had a porous texture. His interest in these originated in a collection of specimens which he had been sent. He had preserved these and made landscapes with them.

${ }^{108}$ Marsigli (n. 105), pp. 55-56 and pp. 60-63; also his 'Lettre touchant quelques branches de corail qui ont fleuri', J. Scavans, 1727, 35, 356-57.

${ }^{100}$ This argument was first described, without disclosing the identity of the author, in R. A. de Reaumur, "Observations sur la formation du corail, et des autres productions appellées plantes pierreuses', Mém. Acad. Sci., 1727, p. 275f. This was not taken seriously until Trembley's discovery of the polyp. A fuller account of Peyssonnel's work then appeared in translation: 'An account of a manuscript treatise, presented to the Royal Society, intituled Traité du Corail ..., Phil. Trans. R. Soc. Lond., 1752, 47, 445-69.

$110 \mathrm{~J}$. Ellis, An Essay towards a Natural History of the Corallines, and other Marine Productions of the like Kind ...., London , 1755, p. 67.

${ }_{111}$ Sir J. E. Smith, A Selection of the Correspondence of Linnaeus, and other Naturalists, London, 1821,2 vols., vol. 1 , p. 218 . Koelreuter also regarded gorgonians, corals and corallines as plants mixed with animal properties. He thought the animal part of their mixed nature was exhibited in the chemical analyses which he performed. J. T. Koelreuter, 'Zoophyti Marini, e Coralliorum Genere, Historia', Novi Comm. Acad. Sci. Imp. Petropolit., 1758-9, 5, 344-73.

118 Ellis (n. 110), p. 79. 


\section{Application of Chemical Criteria to Biological Classification in the 18th Century}

This delighted Stephen Hales, who asked Ellis to acquire more corallines to make a landscape for the Princess Dowager of Wales, and this culminated in Ellis' attempts to classify them. ${ }^{113}$

He likened their slender, jointed branches to moss and admitted that at first, like the botanists, the forms had deceived him into the belief that corallines were plants. But his doubts grew when their texture under the microscope seemed unlike plants. He travelled to Sheppey to study live specimens. His suspicions were confirmed; some specimens exhibited polyps with contracting tentacles. He thought there was also conclusive evidence from chemistry; he wrote: 'These differ from Sea-plants in Texture, as well as Hardness, and likewise in their chymical Productions. For SeaPlants, properly so called, such as the Algae, Fuci, etc., afford in Distillation little or no Traces of a volatile Salt: Whereas all the Corallines afford a considerable Quantity; and in burning yield a Smell somewhat resembling that of burnt Horn, and other animal Substances: Which of itself is a Proof that this Class of Bodies, tho' it has the vegetable Form, yet is not intirely of a vegetable Nature.'114

Ellis was apparently unaware that the interpretation of the chemical evidence was not as straightforward as he had presented it. In the argument which followed Ellis simply tried to persuade his opponents that the chemical phenomena were really as he had described them. Pallas, the natural historian and traveller, had advanced similar chemical evidence in support of the animality of various zoophytes. For example he referred to an analysis on a species of Alcyonaria carried out by his friend S. G. Gmelin. ${ }^{115}$ But he left the corallines until the end of his book, and said they were not really zoophytes, but plants and ought to be left to the botanists. Apart from their nodulous structure and fructification, which he compared to Fuci and Confervae, Pallas said the chemical behaviour of the corallines distinguished them from the zoophytes. He had neither the time nor the opportunity to perform the tests himself; instead he maintained that others had observed no animal oil or volatile salt, and that the odour in burning was more like vegetables. ${ }^{116}$

Ellis took up the challenge and elaborated his chemical evidence to persuade Pallas that he had put the corallines in the wrong kingdom. In a letter ${ }^{117}$ to Linnaeus he described an experiment he had made at the Society for the Encouragement of Arts, Manufactures and Commerce, which he said had convinced the members present of the great difference in odour accompanying the combustion of plants and animals. The Society was investigating the nature of orchell, a lichen employed by dyers to produce a red colour, and had invited members to bring specimens for the next meeting. This was attended by Ellis who noticed that one sample inscribed as orchell was really a coralline. He told the others that while the rest of the samples were vegetable lichens, this was an animal coralline. Then, he recalled: ‘ $\ldots$ in order to convince the Society of the difference, I called for a lighted candle, and having first set fire to the Lichen Roccella, it yielded the same smell that burnt vegetables usually

118 Ibid., pp. v-vi.

114 Ibid., p. 2.

116 P. S. Pallas, Elenchus Zoophytorum, The Hague, 1766, p. 354.

116 Ibid., p. 418.

117 'Extract of a letter from John Ellis, Esquire, F.R.S. to Dr. Linnaeus, of Upsal, F.R.S. on the animal nature of the genus of zoophytes, called Corallina', Phil. Trans. R. Soc. Lond., 1767, 57, 404-27. 


\section{C. Goodman}

do; but when the Coralline ... . was burnt, it filled the room with such an offensive smell like that of burnt bones, or hair, that the door was obliged to be opened, to dissipate the disagreeable scent, and let in fresh air.'118

To deal with Pallas' other objection that corallines gave no animal oil or volatile salts in distillation, Ellis sought the co-operation of Peter Woulfe, ${ }^{119}$ a London chemist and the inventor of the Woulfe bottle, an improvement in the apparatus for performing distillations. Confident that Woulfe would provide accurate results, Ellis gave him a specimen of Corallina officinalis, fresh from the coast near Harwich. Woulfe placed the sample in a retort, fitted to a receiver, and applied a gentle heat for eight hours, collecting the distillate. This was continued at increasing temperatures for two successive periods of six hours. The first fraction contained a little volatile alkali, but its presence was much more noticeable in the subsequent fractions, when ammoniacal salts crystallized; oil with an animal smell also appeared. Woulfe remarked that if the distillation had been hurried the ammoniacal salts would have been missed.

Ellis said that if Pallas tried this analysis, with the requisite care, he would change his opinion. He gave the same advice to Baster, a Dutch naturalist who had argued for the vegetable nature of corallines from their structural resemblance to Confervae. As a further proof he invited his opponents to treat Confervae, fuci or lichens with acid; nothing would happen, he said, whereas corallines would effervesce as their calcareous covering dissolved. ${ }^{120}$

Ellis believed that the calcareous exterior itself revealed the true nature of the corallines, since he thought lime was only produced by animals. ${ }^{121} \mathrm{He}$ was following Linnaeus, who told Ellis that for this reason he had never doubted that the corallines were animal. ${ }^{122}$ Ellis and Linnaeus were wrong, since lime is also produced by marine plants. This was soon demonstrated by Cavolini, ${ }^{123}$ who macerated marine fuci and showed that they effervesced with acids. This falsified Linnaeus' canon 'omnis calx a vermibus', and Cavolini felt free to assert that corallines were plants.

Some of the corallines examined by Ellis were polypiferous invertebrates, and he had correctly concluded that they were animal, though for the wrong reasons; others however were calciferous algae, in which no observer could find polyps. The chemical arguments on which Ellis relied so much were naive and inconclusive, since they ignored the available information on plant analyses, though as has been seen Ellis was not alone in this. Ironically the Corallina officinalis, whose analysis by Woulfe he had particularly valued as a proof of animality, is not an invertebrate animal, but a calciferous alga.

The chemical discussion of the corallines was taken a stage further and related to the wider philosophical question of the chain of being by Durande, ${ }^{124}$ professor of

118 Ibid., pp. 409-10.

110 Ibid., pp. 410-12.

120 Ibid., p. 422.

121 Ellis (n. 117), p. 415 and his The Natural History of Many Curious and Uncommon Zoophytes, London, 1786, p. 108.

122 Smith (n. 111), vol. 1, p. 208. Linnaeus however praised Ellis's work, regarding it as discovering the nature of corallines, ibid., vol. 1, p. 177.

123 F. Cavolini, Memorie per Servire alla Storia de' Polipi marini, Naples, 1785, pp. 81 and 260. For a further discussion of the origin of lime see Guettard (n. 107), vol. 4, pp. 442-45.

19 J. F. Durande, 'Mémoire sur la coralline articulée des boutiques', Nouv. Mém. Acad. Dijon, $1783,2,173-94$. 


\section{Application of Chemical Criteria to Biological Classification in the 18th Century}

botany at Dijon and co-author with Guyton de Morveau of Elémens de Chymie. He thought it was important to reach agreement on whether nature showed continuity or discontinuity in the passage of the species. Were the three kingdoms artificial divisions, in fact linked by terminal members with intermediate properties, so establishing an imperceptible gradation, or were the kingdoms natural discrete divisions with distinctive characteristics? In the latter case, he said, an ambiguous or intermediate class such as the zoophytes would not exist.

Durande decided to investigate the disputed corallines in this context. Chemistry would provide the most important evidence; he said: '.. . it can determine with exactness the vegetable or animal nature of corallines, and this must be consulted.'125

He examined the coralline, which he described as 'from the shops', and which might have been Corallina officinalis. The products of distillation were volatile alkali and a thick oil; the charcoal contained many small shells. He said the shells were accidental. They could account for the apparently animal phenomena and so save the corallines for the botanists. He argued: 'It is easy to explain the presence of volatile alkali in seeing the animal products remaining in the charcoal. Besides even if the corallines alone had furnished the volatile alkali one would not be forced to conclude these were animal; since not only are there various poisonous plants such as hemlock which furnish volatile alkali, but also the umbel.'126

He said the sea was full of insects and these would become attached to the calcareous crust of the corallines. He therefore dissolved the crust in nitric acid, to remove the foreign animals, and distilled what was left. This gave much less volatile alkali, hardly a trace, which he attributed to residual insects, since the charcoal still showed shell fragments which had escaped the action of the acid. In another test the crustless coralline immersed in water produced a vegetable gummy extract. Finally a comparative series of chemical tests on horn convinced him that, contrary to earlier descriptions, this was unlike the substance of corallines. He concluded that corallines not only looked like plants, but really were plants, impregnated with accidental lime and animal matter.

He suggested that this was the way to establish the nature of other ambiguous marine organisms. In opposition to Bonnet and Pallas, who had maintained that nature made no leaps, Durande conjectured that intermediate beings would disappear, as they were placed in one of the discrete kingdoms, showing that nature avoided the 'timid progression' of the continuum.

Durande was aware that there was no complete chemical distinction between animals and plants, and yet in a devious way he had made the evidence appear conclusive. It was not long before the chemistry of the corallines was dismissed as inconsequential. This followed a quantitative analysis of Corallina officinalis by Bouvier, ${ }^{127}$ who employed nitric acid and looked for azote and prussic acid, as Fourcroy had recommended. He also observed flocculent white precipitates, characteristic of coagulated albumen. He clearly regarded the quantities of nitrogenous material as significant, and

125 Ibid., p. 186. ${ }^{126}$ Ibid., p. 189.

127 A. M. J.(?) Bouvier, 'Analyse de la coralline, Corallina officinalis, de Linnaeus', Ann. Chim., $1791,8,308-18$. The importance that he attached to the quantities of nitrogenous matter can be seen from his analysis of another coralline, which he correctly regarded as a sea-weed; Bouvier, 'Analyse de la coralline de Corse, fucus helminthocorton', Ann. Chim., 1791, 9, 83-95. 


\section{C. Goodman}

he mistakenly interpreted the cells of this plant as the residence of polyps.

This analysis was discussed by Olivi, who made a study of marine creatures in the Adriatic. He denied that Bouvier's work supported the view that corallines were animal. In a statement which showed the clearest appreciation of the inconclusive nature of chemical evidence in biological classification, he wrote: 'In the former state of chemistry the existence of albuminous substances ... would have been considered as decisive characteristics indicating an animal nature. But now that Fourcroy has obtained these from plants, now that the existence of azote has been discovered in some plants, particularly cruciferous plants, ... this result can no longer make much impression on the minds of naturalists in their decisions on the nature of productions; and therefore they must investigate the solution of this interesting problem by other means.' ${ }^{128}$

Nevertheless the resort to chemistry to settle the kingdoms of cryptogamia and zoophytes would continue deep into the nineteenth century.

The attempt to bring chemistry into biological classification in the eighteenth century was a new development, but it was not successful. It is clear, from the contradictory statements of those who had carried out the chemical work, that they had failed to establish the fundamentals for such a scheme. The search for qualitative chemical differences in the kingdoms of nature wavered on the unresolved difficulty of the movement of matter between the kingdoms. Nor were the quantitative differences clear; it was significant that Fourcroy was never able to state actual figures to express these.

The attempt was unsuccessful because it was impossible. Neither chemical criteria alone, nor their combination with another set of criteria, can separate animals and plants. But the intrusion of chemistry into biological classification was another indication of the growing importance of that science in the eighteenth century.

128 G. Olivi, Zoologia Adriatica, Bassano, 1792, p. 280. 